\title{
Analisa Penerapan Manajemen Waktu Pada Proyek Beton Penangkis Ombak
}

\author{
Sugiyanto $^{1}$, Saiful Fallah ${ }^{2}$ \\ Prodi Teknik Sipil Fakultas Teknik Universitas Sunan Bonang Tuban Jawa Timur ${ }^{1,2}$ \\ Email: irsugianto6@gmail.com ${ }^{1}$ \\ DOI: http://dx.doi.org/10.31869/rtj.v4i2.2385
}

\begin{abstract}
Abstrak: Penelitian ini merupakan studi kasus pemasangan beton pada PT. Trans Pacific Petrochemical Indotama Tuban. Penelitian ini dilatarbelakangi oleh adanya permasalahan yang dihadapi oleh perusahaan tersebut karena lokasinya berada di tepi laut terhadap adanya keropos tanah yang bisa mengancam keberadaan akses dan peralatan vital perusahaan. Dari hasil investigasi penyebab adanya keropos tanah tersebut disebabkan karena keberadaan penangkis ombak tidak mampu lagi bekerja dengan performa yang diharapkan karena mengalami korosif dan berkarat sehingga tidak mampu mencegah adanya erosi dan abrasi ombak laut. Berdasarkan hasil investigasi tersebut pula, perusahaan mengambil langkah untuk membuat penangkis ombak yang baru terbuat dari komponen beton dengan mempertimbangkan umur ekonomis, efektivitas kerja dan biaya pemeliharaan. Dalam rangka untuk mengetahui apakah upaya teknik pengendalian waktu pelaksanaan proyek dilakukan secara efektif pada proyek beton penangkis ombak, maka diperlukan analisa penerapan manajemen waktu pada proyek tersebut. Teknik pengendalian pada proyek yang diteliti dilakukan dengan menggunakan metode nilai hasil (earned value) yang merupakan upaya pengendalian terpadu pelaksanaan waktu proyek dengan aplikasi Kurva S. Berdasarkan analisa penerapan manajemen waktu pada proyek yang diteliti, didapatkan informasi waktu pelaksanaan proyek pada minggu ke-1, ke-2, ke-3 dan minggu ke-7 berjalan dengan lebih lambat dari jadwal yang direncanakan; kemudian pada minggu ke-4, ke-5, ke-6, ke-8 dan minggu ke-9 berjalan dengan lebih cepat dari jadwal yang direncanakan; dan akhirnya pada minggu ke-10 pelaksanaan proyek mencapai penyelesaian sesuai dengan jadwal yang direncanakan. Berdasarkan atas analisa kinerja jadwal dengan menggunakan metode nilai hasil (earned value method) pada pelaksanaan proyek beton penangkis ombak, didapatkan hasil perhitungan varian jadwal (schedule variance) $S V=0$ dan indek kinerja jadwal (schedule performance index) $S P I=1$. Dengan demikian, hasil analisa pelaksanaan proyek yang diteliti secara meyakinkan menunjukkan terjadinya jadwal pelaksanaan proyek sesuai dengan jadwal yang telah direncanakan (on schedule).
\end{abstract}

Kata Kunci: Proyek, Manajemen Waktu, Jadwal dan Nilai Hasil

Abstract: This research is a case study of concrete installation at PT. Trans Pacific Petrochemical Indotama Tuban. This research is motivated by the problems faced by PT. Trans Pacific Petrochemical Indotama Tuban because of its location on the edge of the sea due to the presence of porous soil that could threaten the existence of access and vital equipment of the company. From the results of the investigation, the cause of soil loss is due to the presence of wave repellents that are no longer able to work with the expected performance because they are corrosive and corroded so that they are unable to prevent erosion and sea wave abrasion. Based on the results of the investigation, the company also took steps to make a new wave barrier made of concrete components by considering the economic age, work effectiveness and maintenance costs. In order to determine whether the technical effort to control the project implementation time is carried out effectively on a concrete wave repellent project, it is necessary to analyze the application of time management on the project. The control technique in the project under study was carried out using the earned value method, which is an integrated control effort for the implementation of the project time with the S Curve application. Based on the analysis of the application of time management in the project under study, information on the project implementation time was obtained in week 1, 2nd, 3rd and 7th weeks progressing slower than planned schedule; then at the 4th, 5th, 6th, 8th and 9th weeks went ahead of the planned schedule; and finally in the 10th week of the project implementation reached completion according to the planned schedule. Based on the analysis of schedule performance using the earned value method on the implementation of the wave-repelling concrete project, the calculation results of 
the schedule variance $S V=0$ and the $S P I=1$ schedule performance index. Thus, the results of the analysis of project implementation that are researched conclusively show that the project implementation schedule is in accordance with the planned schedule (on schedule).

\section{Keywords: Project, Time Management, Schedule and Earned Value}

\section{PENDAHULUAN}

PT. Trans Pacific Petrochemical Indotama (TPPI), merupakan perusahaan kilang minyak yang berlokasi di Desa Remen Kecamatan Jenu Kabupaten Tuban Propinsi Jawa Timur. Perusahaan ini diprediksi di masa mendatang akan menjadi perusahaan strategis nasional mengingat hingga saat ini, negara kita sedang menggiatkan langkah untuk memberantas mafia migas salah satunya dengan meningkatkan potensi kapasitas produksi kilang minyak sehingga tidak selalu tergantung pada kegiatan impor minyak dari negara lain. Hal ini ditandai dengan seringnya frekuensi kunjungan para pejabat negara yang terkait dengan industri ini untuk meninjau ke lokasi perusahaan bahkan presiden Joko Widodo sudah beberapa kali datang ke lokasi tersebut. Perusahaan ini dalam menjalankan aktivitas proses produksi menggunakan bahan baku berupa condensate, yang disuplai dari lokasi-lokasi refinery unit $(R U)$ yang terdiri dari $R U$ IV Pertamina Cilacap, $R U$ V Pertamina Balikpapan dan $R U$ VI Pertamina Balongan (Indramayu). Produk-produk yang dihasilkan meliputi bahan bakar minyak (BBM) jenis pertamax, solar, bensin dan avtur dengan total kapasitas produksi 10.000 barel per hari.

PT. Trans Pacific Petrochemical Indotama (TPPI) Tuban dalam sejarah awalnya merupakan perusahaan swasta nasional yang sempat berhenti beroperasi pada saat terjadi krisis moneter pada tahun 1998 dan kemudian diambil alih oleh pertamina pada tahun 2013 hingga sekarang. Dengan lokasi perusahaan yang cukup strategis karena berada di tepi laut, sangat memudahkan kegiatan bongkar muat dengan menggunakan fasilitas transportasi kapal laut. Berdasarkan atas lokasi ysng berada di tepi laut pula terdapat permasalahan yang cukup serius dihadapi oleh perusahaan, yaitu terjadinya erosi dan abrasi pantai yang merupakan ancaman terhadap keberadaan fasilitas di flare stack dan beberapa bagian vital yang lain milik perusahaan. Ancaman tersebut berupa hantaman arus ombak yang semakin kuat yang menyebabkan kerusakan pada beberapa bagian bangunan pemecah gelombang di pelabuhan milik perusahaan tersebut. Kejadian ini dari perjalanan dari waktu ke waktu diperkirakan berlanjut semakin parah kondisinya dengan laju ombak yang semakin tinggi dan berdasarkan identifikasi menunjukkan terjadi kondisi keropos tanah di bibir pantai semakin meluas. Dengan adanya permasalahan ini, pihak perusahaan merasa perlu untuk segera menghentikan atau setidaknya mengurangi laju ombak seoptimal mungkin untuk mencegah terjadinya keropos tanah yang akan memperparah keadaan.

Berdasarkan atas hasil diskusi antara manajemen perusahaan dengan tim engineering PT. TPPI Tuban dan juga dari temuan hasil investigasi kondisi di lapangan, diketahui pula telah terjadi kerusakan pada pemecah gelombang eksisting, yang struktur utamanya berupa sheet pile baja cellular type mengalami korosif sehingga tidak efektif lagi fungsinya untuk memecah gelombang. Oleh karena itu, maka pihak manajemen perusahaan mengambil langkah inisiatif untuk melakukan perencanaan dan perancangan bangunan pemecah gelombang yang baru sebagai pengganti bangunan pemecah gelombang eksisting berupa beton penangkis ombak. Langkah ini mempertimbangkan dari kondisi umur ekonomis dan biaya pemeliharaan, meskipun pada proses pembuatannya akan membutuhkan anggaran biaya yang relatif cukup besar.

Pada pekerjaan pemasangan beton penangkis ombak diperlukan manajemen waktu yang tepat mengingat pekerjaan ini berada di tepi laut yang rawan terjadi keterlambatan bila tidak ditangani secara baik. Winoto (2014) mengingatkan bahwa sebuah proyek meliputi tugas-tugas tertentu yang dirancang secara khusus dengan hasil dan waktu yang telah ditentukan terlebih dahulu dan dengan keterbatasan sumber daya. Demikian pula, Husen (2009) mengatakan bahwa perencanaan suatu proyek dapat diartikan sebagai pemberi pegangan bagi pelaksana mengenai alokasi sumberdaya untuk 
melaksanakan kegiatan dan memastikan penggunaan sumber daya secara efektif dan efisien. Demikian pula, Pastiarsa (2015) menyatakan bahwa tujuan manajemen proyek adalah mengelola suatu proyek sedemikian rupa sehingga diperoleh suatu hasil (deriverables) yang memenuhi skop dan persyaratan teknis sesuai batas anggaran dan waktu yang telah ditentukan serta pada level resiko, mutu, keselamatan dan keamanan yang dapat ditolerir. Lebih lanjut, Handoko (1999) menjelaskan secara lebih rinci bahwa tujuan manajemen proyek adalah sebagai berikut:

1. Tepat anggaran (on budget), yaitu biaya yang harus dikeluarkan sesuai dengan anggaran yang telah ditetapkan.

2. Tepat waktu (on schedule), yaitu waktu atau jadwal yang merupakan salah satu sasaran utama proyek, keterlambatan akan mengakibatkan kerugian; seperti penambahan biaya, kehilangan kesempatan produk memasuki pasar dan kerugian lainnya.

3. Tepat spesifikasi (on specification), dimana proyek harus sesuai dengan spesifikasi mutu yang telah ditetapkan.

Husen (2011) menyatakan bahwa evaluasi proyek untuk mengendalikan waktu dapat dilakukan dengan metode nilai hasil (earned value). Pada penerapan metode tersebut adalah dengan aplikasi penggunaan Kurva S untuk melakukan pengendalian dalam pelaksanaan suatu proyek. Bentuk Kurva S tersebut adalah berupa kurva nilai hasil untuk mengevaluasi penggunaan biaya dan jadwal waktu proyek sekaigus dan lebih realistis dari keadaan yang terjadi di lapangan. Kurva $S$ akan menggambarkan kemajuan volume pekerjaan yang diselesaikan sepanjang siklus proyek. Kurva S sangat bermanfaat untuk dipakai sebagai laporan bulanan dan laporan kepada pimpinan proyek, karena kurva ini dapat dengan jelas menunjukkan kemajuan proyek dalam bentuk yang mudah dipahami. Dalam rangka untuk mendukung kepentingan dan demi suksesnya pelaksanaan proyek yang dilakukan oleh PT. TPPI Tuban terhadap permasalahan erosi dan abrasi laut untuk mewujudkan bangunan pemecah gelombang yang baru, maka dirasa sangat perlu untuk dilakukan penelitian tentang analisa penerapan manajemen waktu pada proyek beton penangkis ombak.

\section{METODE PENELITIAN}

Tempat pelaksanaan penelitian ini dilakukan di lokasi Proyek Beton Penangkis Ombak, yang berlokasi di dalam area perusahaan PT. Trans Pacific Petrochemical Indotama (TPPI) Desa Remen Kecamatan Jenu Kabupaten Tuban Propinsi Jawa Timur, dengan data-data umum proyek sebagai berikut ini:

1. Nama Proyek : Proyek Beton Penangkis Ombak

Pengguna Proyek: PT. Trans Pacific Petrochemical Indotama (TPPI) Tuban

2. Lokasi Proyek : Desa Remen Kecamatan Jenu Kabupaten Tuban

3. Nilai Proyek : Rp. 900.000 .000 (Belum termasuk PPN 10\%)

4. Sumber Dana : Repair \& Renovation Budget Tahun 2020

5. Waktu Proyek : 11 Februari 2020 sampai 21 April 2020

6. Pelaksana Proyek: CV. Anugerah

7. Tahun Anggaran : Tahun 2020

Waktu pelaksanaan penelitian ini dilaksanakan mengikuti waktu berjalannya Proyek Beton Penangkis Ombak sesuai dengan skedul atau jadwal pelaksanaan adalah 70 (tujuh puluh) hari kerja yang dimulai dari tanggal 11 Februari 2020 sampai berakhir dengan tanggal 21 April 2020. Untuk memudahkan analisis dan pengolahan data, maka pengamatan dan pengumpulan data penelitian dibagi dalam periode mingguan terdiri sebagai berikut:

Minggu ke-1 : 11/02 - 17/02 tahun

2020 (durasi 7 hari)

$$
\text { Minggu ke-2 : 18/02 - 24/02 tahun }
$$

2020 (durasi 7 hari)

Minggu ke-3 : 25/02 - 03/03 tahun

2020 (durasi 7 hari)

Minggu ke-4 : 04/03 - 10/03 tahun

2020 (durasi 7 hari)

Minggu ke-5 : 11/03 - 17/03 tahun

2020 (durasi 7 hari)

Minggu ke-6 : 18/03 - 24/03 tahun

2020 (durasi 7 hari)

Minggu ke-7 : 25/03 - 31/03 tahun

2020 (durasi 7 hari)

Minggu ke-8 : 01/04 - 07/04 tahun

2020 (durasi 7 hari)

Minggu ke-9 : 08/04 - 14/04 tahun

2020 (durasi 7 hari) 
Minggu ke-10 : 15/04 - 21/04 tahun 2020 (durasi 7 hari)

Total ada 10 minggu pengamatan (Total durasi 70 hari).

Metode pengumpulan data yang dilaksanakan pada penelitian analisa penerapan manajemen waktu pada proyek beton penangkis ombak adalah terdiri dari:

a. Data Primer

Data ini merupakan data penelitian yang diperoleh secara langsung dari sumber data pihak pertama, baik melalui pencatatan, pengukuran ataupun penghitungan data terdiri dari:

1) Biaya Aktual Pengeluaran Proyek

Data ini merupakan biaya aktual pelaksanaan proyek dalam penerapan metode nilai hasil (earned value) dibutuhkan untuk analisa pengendalian waktu pelaksanaan proyek yang diteliti, diperoleh secara langsung dari pihak yang punya kewenangan (otoritas) dalam pembukuan dan administrasi pengeluaran proyek (project accounting manager). Pencatatan pengeluaran aktual proyek ini dinyatakan dalam satuan mata uang rupiah ( $R p)$ dan bilamana ada pengeluaran dalam bentuk mata uang lainnya, maka dikonversi ke dalam mata uang rupiah sesuai dengan patokan kurs yang berlaku pada saat itu. Untuk memudahkan dalam pengolahan data, maka dalam pelaksanaan penelitian ini penghitungan biaya aktual pengeluaran proyek dilakukan dengan sistem pencatatan mulai dari awal proyek berjalan hingga proyek selesai dan kemudian direkap tiap hari, disusun dan ditabulasi sesuai dengan periode mingguan yang sudah ditentukan untuk kepentingan analisa manajemen waktu, selanjutnya dikomulatifkan menjadi biaya total pengeluaran proyek.

2) Waktu Pelaksanaan Berjalannya Proyek Data ini diperoleh secara langsung terhadap waktu pelaksanaan berjalannya proyek, dengan memantau kondisi aktual penyelesaian tiap periode mingguan proyek sesuai dengan durasi 7 hari kerja untuk kebutuhan analisa menggunakan metode nilai hasil (earned value), dihitung waktu yang dibutuhkan untuk penyelesaian tiap periode tersebut. Dengan demikian, pencatatan dalam pelaksanaan menggunakan metode nilai hasil pada penelitian ini, dilakukan penghitungan waktu pelaksanaan proyek sesuai dengan periode mingguan yang telah ditentukan untuk kebutuhan analisa dan pengolahan data. Pencatatan dilakukan mulai dari awal pelaksanaan proyek sampai waktu proyek dinyatakan selesai dan diterima dengan baik oleh pemilik proyek.

b. Data Sekunder

Data ini merupakan data yang didapat dari sumber pihak kedua yang terkait dengan proyek yang sedang diteliti (data tidak langsung) yang diperlukan untuk mendukung kebutuhan analisa data, baik secara langsung maupun tidak langsung pada pelaksanaan penelitian ini, terdiri dari:

1) Rancangan atau disain proyek

Rancangan atau disain proyek meliputi tes tanah, denah proyek, rancangan kekuatan struktur beton, desain metode kerja, gambar kerja, dokumentasi dan lainnya.

2) Rancangan anggaran belanja proyek (RAB)

Rancangan anggaran belanja proyek terdiri dari biaya-biaya yang tercantum dalam daftar rekapitulasi biaya meliputi jenis pekerjaan, volume pekerjaan, satuan, harga satuan pekerjaan, harga satuan dan jumlah upah pekerja (man power), bahan bakar minyak (BBM), jumlah dan harga satuan bahan, analisa harga satuan pekerjaan, administrasi \& umum, manajemen dan biaya-biaya lainnya.

3) Rencana kerja dan syarat pelaksanaan proyek (RKS)

Rencana kerja dan syarat-syarat pekerjaan pelaksanaan proyek terdiri dari keterangan dan informasi tentang proyek yang dikerjakan, penjelasan umum dan teknis, peraturan teknis, syarat pelaksanaan dan persyaratan administrasi.

4) Penjadwalan waktu proyek (time schedule)

Penjadwalan waktu proyek berisi uraian-uraian aktivitas atau kegiatan beserta kebutuhan waktu pelaksanaan 
dan hingga kapan proyek tersebut harus diselesaikan.

Pengukuran variabel dalam pelaksanaan penelitian ini adalah terdiri dari pengukuran variabel yang dibutuhkan dalam proses pengolahan data dengan menggunakan metode nilai hasil (earned value) pada proyek beton penangkis ombak, terdiri dari analisa schedule variance $(S V)$ dan analisa schedule performance index $(S P I)$. Dengan demikian, pengukuran variabel terdiri sebagai berikut ini:

1. Variabel $A C W P$

Actual Cost for Work performed (ACWP) adalah jumlah biaya aktual dari pekerjaan yang telah dilaksanakan. $A C W P$ didapat dari data akutansi pada tanggal pelaporan, yaitu catatan segala pengeluaran biaya aktual dari paket kerja. ACWP merupakan biaya aktual yang diperlukan untuk membiayai proyek dari awal hingga selesai, disusun dalam pengeluaran aktual mingguan (per minggu) sesuai dengan kebutuhan yang diperlukan dalam analisis dan pengolahan data pada penelitian ini.

2. Variabel $B C W P$

Budgeted Cost for Work Performed $(B C W P)$ adalah nilai yang diterima dari penyelesaian pekerjaan selama periode waktu tertentu. $B C W P$ inilah yang disebut earned value, dihitung berdasarkan akumulasi dari pekerjaan-pekerjaan yang telah diselesaikan. Variabel $B C W P$ dapat diperoleh dengan perhitungan rumus sebagai berikut:

$B C W P=$ Bobobt Penyelesaian Pekerjaan (\%) X Komulatif Anggaran

3. Variabel $B C W S$

Budgeted Cost for Work Scheduled (BCWS) adalah biaya yang dialokasikan berdasarkan rencana kerja yang disusun terhadap waktu. $B C W S$ dihitung dari penjumlahan biaya yang direncanakan untuk pekerjaan dalam periode waktu tertentu. Variabel $B C W S$ dalam aplikasi dalam proyek adalah biaya yang dianggarkan untuk menyelesaikan kegiatan proyek, disusun dalam rekap anggaran mingguan (per minggu) sesuai dengan kebutuhan yang diperlukan dalam analisis dan pengolahan data pada penelitian ini.
4. Indikator $S V$

Schedule variance $(S V)$ atau varian jadwal adalah perbedaan bagian pekerjaan yang dapat dilaksanakan $(B C W P)$ dengan bagian pekerjaan yang direncanakan (BCWS). Nilai indikator $S V$ dapat diperoleh dengan perhitungan rumus seperti di bawah ini:

$S V=B C W P-B C W S$

5. Indek $S P I$

Schedule performance index (SPI) atau indek kinerja jadwal adalah perbandingan antara penyelesaian pekerjaan di lapangan $(B C W P)$ dengan rencana kerja pada periode waktu tertentu $(B C W S)$. Nilai indek SPI dapat diperoleh atau dihitung dengan perhitungan menggunakan rumus sebagai berikut ini:

$$
S P I=B C W P: B C W S
$$

Pengolahan dan analisis data pada pelaksanaan penelitian tentang analisa penerapan manajemen waktu pada proyek beton penangkis ombak adalah dengan menggunakan perangkat lunak (software) sebagai berikut ini:

1. Analisi deskriptif kuantitatif menggunakan software komputer yang terdiri dari microsoft excel. Analisis ini dilakukan untuk menghitung dan mengolah data kuantitatif terdiri dari data anggaran biaya, bobot biaya pelaksanaan proyek, nilai hasil (earned value), rincian biaya pada pelaksanaan proyek, penghitungan indikator kinerja jadwal, serta penghitungan indek kinerja jadwal.

2. Analisi deskriptif kuantitatif menggunakan software komputer yang terdiri dari microsoft word. Analisis ini dilakukan untuk memvisualisasikan grafik dari Kurva $S$ yang menggambarkan progress kemajuan proyek yang sedang diteliti. Bentuk Kurva $S$ terdiri dari pemaduan kemajuan setiap tambahan waktu untuk mendapatkan kemajuan komulatif yang digunakan dalam pemantauan pekerjaan. Ukuran kemajuan dititikberatkan pada progress kerja dan biaya. Sumbu X menunjukan skala waktu (durasi pelaksanaan proyek), sedangkan pada sumbu Y merupakan skala biaya atau 
prestasi kerja, yang terdiri dari variabelvariabel $B C W S, A C W P$ dan $B C W P$.

\section{HASIL DAN PEMBAHASAN}

\section{Gambaran Umum Obyek Penelitian}

Pada proyek yang diteliti ini merupakan proyek beton penangkis ombak yang ditujukan untuk mengganti penangkis ombak yang sebelumnya sudah ada. Proses penggantian penangkis ombak milik PT. Trans Pacific Petrochemical Indotama (TPPI) Tuban ini dilakukan dengan pertimbanganpertimbangan sebagai dasar keputusan adalah sebagai berikut:

1. Kemampuan penangkis ombak yang ada tidak mampu bekerja dengan performa yang diharapkan karena sudah tidak mampu menahan terjadinya proses erosi dan abrasi laut.

2. Struktur penangkis ombak lama terbuat dari komponen logam baja dan karena sifat air laut mengandung kadang garam tinggi menyebabkan kondisi korosif dan berkarat.

3. Kondisi keropos tanah di struktur badan penangkis ombak semakin meluas karena adanya hantaman ombak yang cukup keras terutama pada saat cuaca buruk karena angin kencang.

4. Berdasarkan atas ketahanan terhadap sifat korosif air laut dan umur ekonomis yang lebih panjang, maka manajemen PT. Trans Pacific Petrochemical Indotama Tuban memutuskan untuk mengganti penangkis ombak yang ada dengan penangkis ombak baru yang terbuat dari beton.

5. Pembuatan penangkis ombak yamg baru diwujudkan dengan menyelenggarakan adanya proyek beton penangkis ombak dengan melibatkan kontraktor profesional untuk merealisasikannya.

Untuk memvisualisasikan kondisi kerusakan karena kemampuan penangkis ombak yang sudah ada tidak mampu bekerja sebagaimana mestinya, diperlihatkan pada Gambar 1 di bawah ini:

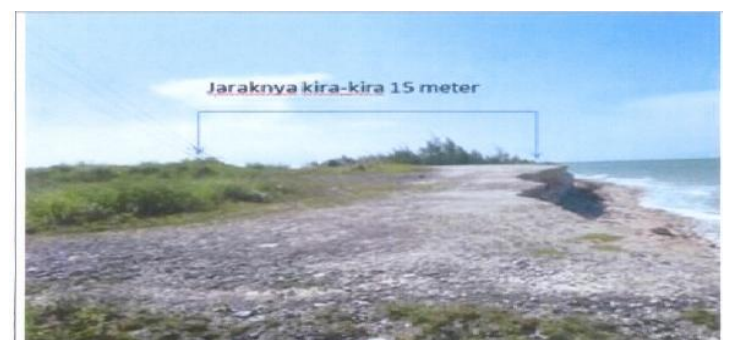

Gambar 1. Kondisi Kerusakan di Bibir Pantai Milik PT. TPPI Tuban
Pada Gambar 1 dapat diamati kondisi kerusakan bagian yang mengalami keropos tanah sehingga memerlukan penganganan yang serius dilakukan oleh manajemen perusahaan. Langkah yang telah diputuskan untuk memecahkan permasalahan tersebut oleh manajemen perusahaan adalah dengan melakukan penggantian penangkis ombak lama yang terbuat dari komponen baja dengan penangkis ombak baru, yang terbuat dari komponen beton seperti ditampilkan pada Gambar 2 berikut ini:



Gambar 2. Proyek Beton Penangkis Ombak Milik PT. TPPI Tuban

Berdasarkan atas yang ditampakkan pada Gambar 2 di atas, maka diperlihatkan penampang penangkis ombak yang baru terbuat dari struktur komponen beton. Proyek ini dianggarkan menelan biaya $\mathrm{Rp}$. 900.000.000 (belum termasuk PPN 10\%) yang dialokasikan dari sumber dana milik perusahaan PT. Trans Pacific Petrochemical Indotama (TPPI) Tuban sebagai pengguna proyek dari pos pengeluaran repair and renovation budget.

Oleh karena lokasi pengerjaan proyek berada persis di tepi laut dan jauh dari lokasi pemukiman penduduk, maka membutuhkan kriteria pemilihan kontraktor yang handal dan profesional serta berpengalaman dalam merealisasikan proyek tersebut. Setelah diadakan lelang pekerjaan kontruksi ini, didapatkan kontraktor CV. Anugerah sebagai pemenangnya dan proyek beton beton penangkis ombak ini dijabarkan dalam uraian pekerjaan yang direncanakan dan dibuat kontrak kontruksi antara pihak pengguna proyek dan pihak kontraktor penyedia jasa 
seperti ditampilkan pada Tabel 1 di halaman berikut ini:

Tabel 1. Uraian Pekerjaan Proyek Beton Penangkis Ombak



Sumber: CV. Anugerah (2020)

\section{Penghitungan Variabel Nilai Hasil Proyek Beton Penangkis Ombak}

Berdasarkan atas data yang diperoleh dari sumber data pihak kedua didapatkan Rancangan Anggaran Belanja (RAB) pada proyek beton penangkis ombak, seperti ditampilkan pada Tabel 2 di bawah ini:
Tabel 2. Rancangan Anggaran Belanja (RAB) Proyek Beton Penangkis Ombak

\begin{tabular}{|c|c|c|}
\hline \multirow{2}{*}{ Ming } & Ha & Biaya RAB (Variabel $B C W S$ )
\end{tabular} \begin{tabular}{c|c|c|c} 
Ming & ri & Per Minggu & Komulatif
\end{tabular} \begin{tabular}{r|r}
$\begin{array}{c}\text { gut Hakga } \\
\text { Ke- } \\
\text { Satuan }\end{array}$ & Totpl Biaya
\end{tabular}$\quad$ (Rp)

\begin{tabular}{c|c|c|r|r}
\hline & Rp & $25.100 . \mathrm{Rp}$ & 25.100. \\
\hline Lot & 7.500 .000 & 00.600 .000 & 000
\end{tabular}

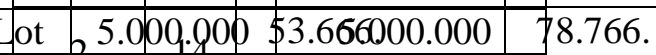

\begin{tabular}{l|l|l|r|r}
\hline 2 & & 50.500 .000 & 500 \\
\hline 3 & 21 & 78.676. & 157.443
\end{tabular}

\begin{tabular}{|c|c|c|r|r}
\hline 3 & 21 & 78.676. & 157.443 \\
& & 600 & .100 \\
\hline & & 82.558. & 240.001
\end{tabular}

\begin{tabular}{cc|c|c|r} 
& 4 & 28 & 82.558. & 240.001 \\
on & 135.000 & 14080000.000 & .500 \\
\hline
\end{tabular}

\begin{tabular}{r|r|r|r|r}
5 & 35 & 105.332 & 345.333 \\
& .200 & .700 \\
\hline
\end{tabular}

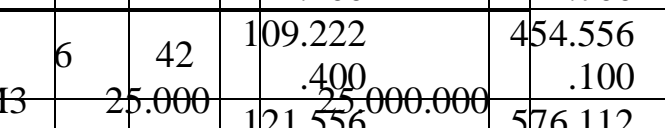

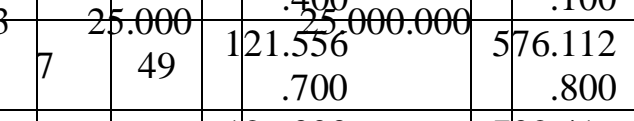

\begin{tabular}{l|r|r|r}
8 & 56 & 126.303 & 702.416 \\
.200 & .000 \\
\hline
\end{tabular}

\begin{tabular}{ll|l|r|}
3 & $93.2506000^{104} 1942$ \\
.000 & 000.000 & 807.358 \\
.000
\end{tabular}

\begin{tabular}{r|r|r|r}
10 & 70 & 92.642. & 900.000 \\
& 000 & .000 \\
\hline
\end{tabular}

Sumber: CV. Anugerah (2020)

\begin{tabular}{l|l|l} 
Ton & 135.000 & 255.420 .000
\end{tabular}

Pada Tabel 2 tersebut, diperlihatkan

Ton bahwa Rangangan Anggaran Belanja Proyek tersebut terjadwal dalam periode mingguan dengan durasi pengerjaan 70 hari kalender


akhir penyelesaian proyek 21 April 2020.

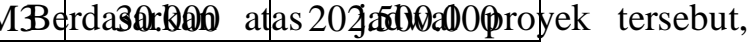
M3naka 20!00k meBo!døblan analisa dan pengolahan data padaloegebtian ini, durasi

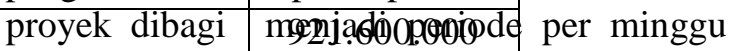
sehingga didapardo!.000. dera pengamatan sebanyak 10 (sepubdy.oogi.oggu. Pada masing-

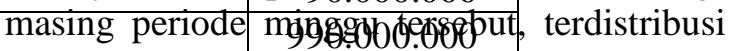
besarnya anggaran tiap periode per minggu dengan nilai anggaran terbesar berada pada aktivitas minggu ke-8 sejumlah Rp. 126.303.200 atau $14 \%$ dari total anggaran proyek.

Besarya anggaran terkecil berada pada aktivitas minggu ke-1 yang merupakan awal dimulainya proyek senilai Rp. 25.100.000 atau hampir 3\% dari nilai total anggaran proyek. Pada tabel tersebut juga disajikan data secara komulatif kebutuhan nilai anggaran proyek adalah sebesar Rp. 900.000.000 (\#Terbilang sembilan ratus juta rupiah\#). Besanya nilai 
anggaran komulatif yang dituangkan dalam RAB dalam teknik pengendalian proyek dengan menggunakan metode nilai hasil (earned value method) dinamakan dengan variabel Budgeted Cost for Work Schedule (BCWS).

Rani (2016) mengatakan bahwa manajemen dalam pelaksanaan konstruksi dilakukan dengan perencanaan dan penjadwalan, yaitu proses yang mencoba meletakkan dasar tujuan dan dasar sasaran termasuk menyiapkan segala sumber daya untuk mencapai tujuan dan sasaran tersebut. Tujuan dalam pelaksanaan konstruksi adalah untuk menyelesaikan pekerjaan sesuai dengan sasaran proyek dan mendapat keuntungan dari total biaya yang telah dikeluarkan. Berkaitan dengan pelaksanaan dalam penelitian mengenai analisa penerapan manajemen waktu pada proyek yang diteliti, maka dibutuhkan data pengeluaran aktual pada pelaksanaan proyek beton penangkis ombak terdiri dari rekapitulasi atas biaya-biaya yang meliputi biaya tenaga kerja (man power), material \& bahan, bahan bakar minyak (BBM), administrasi \& umum, peralatan dan lain-lain sebagainya. Berdasarkan atas hasil rekapitulasi biaya aktual proyek pada obyek yang diteliti, dapat disajikan pada Tabel 3 berikut ini:

Tabel 3. Biaya Aktual Proyek Beton Penangkis Ombak

\begin{tabular}{|c|c|c|}
\hline \multicolumn{2}{|c|}{ Penangkis Ombak } & \multirow{2}{*}{ 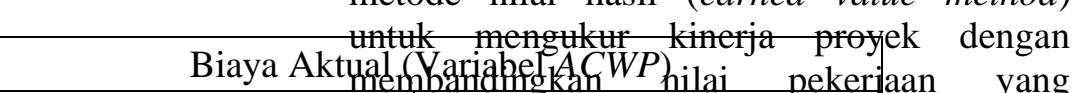 } \\
\hline \multirow{2}{*}{ Minggu Ke- } & \multirow{2}{*}{ Hari Ke- } & \\
\hline & & ACWP Per minggu (Røi)anggarkGiWReK@mulatifaRpang diselesaikan \\
\hline 1 & 7 &  \\
\hline 2 & 14 & 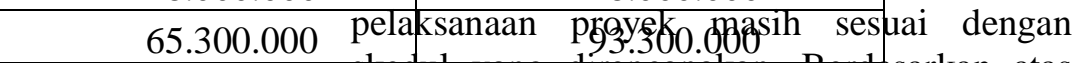 \\
\hline 3 & 21 & 95.777 .500 skectut yang direncanakan. Berdasarkan atas \\
\hline 4 & 28 &  \\
\hline 5 & 35 & 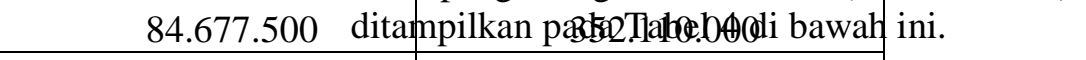 \\
\hline 6 & 42 & 90.501 .000 \\
\hline 7 & 49 & 125.332 .500 \\
\hline 8 & 56 & 150.778 .500 \\
\hline
\end{tabular}

Tabel 4. Nilai Hasil (Earned Value) Pelaksanaan Proyek Beton Penangkis Ombak (Variabel BCWP).

\begin{tabular}{|c|c|c|c|}
\hline \multirow{2}{*}{ Minggu ke- } & \multirow{2}{*}{ Hari Ke- } & Bobot Penyelesaian & Nilai Hasil (Variabel $B C W P$ ) \\
\cline { 3 - 4 } & & $\%$ & $\mathrm{Rp}$ \\
\hline 1 & 7 & 5,50 & 49.500 .000 \\
\hline 2 & 14 & 10,00 & 90.000 .000 \\
\hline 3 & 21 & 18,00 & 162.000 .000 \\
\hline 4 & 28 & 24,50 & 220.500 .000 \\
\hline
\end{tabular}


Vol. 4 No.2 Juni 2021

http://jurnal.umsb.ac.id/index.php/RANGTEKNIKJOURNAL

\begin{tabular}{|c|c|c|c|}
\hline 5 & 35 & 34,00 & 306.000 .000 \\
\hline 6 & 42 & 50,50 & 454.500 .000 \\
\hline 7 & 49 & 65,00 & 585.000 .000 \\
\hline 8 & 56 & 70,00 & 630.000 .000 \\
\hline 9 & 63 & 85,00 & 765.000 .000 \\
\hline 10 & 71 & 100,00 & 900.000 .000 \\
\hline
\end{tabular}

Sumber: Data diolah

Seperti yang disajikan pada Tabel 4, dapat dilihat persentase bobot penyelesaian pekerjaan (\%) dan hasil penghitungan nilai hasil yang diperoleh dalam pelaksanaan proyek yang diteliti. Pada tabel tersebut dapat diamati bahwa berdasarkan bobot penyelesaian proyek $(\%)$ diketahui pada awal pelaksanaan pada minggu ke-1, ke-2 dan ke-3 proyek berjalan sangat lambat, kemudian meningkat secara progresif pada minggu ke- 4 , ke-5, dan ke-6 hingga minggu selanjutnya sampai pada minggu ke-10 proyek selesai dikerjakan.

Nilai hasil (earned value) adalah hasil yang didapat berdasarkan pekerjaan yang telah diselesaikan dan dihitung berdasarkan persentase bobot yang didapat dikalikan dengan komulatif anggaran (nilai kontrak). Berdasarkan atas nilai hasil yang telah didapatkan dalam pelaksanaan proyek pada obyek yang diteliti dalam penjumlahan komulatif diperoleh jumlah sebesar Rp. 900.000.000 (\#Terbilang sembilan ratus juta rupiah\#), dalam teknik pengendalian proyek menggunakan metode nilai hasil disebut variabel Budgeted Cost for Work Performed $(B C W P)$. Untuk mendapatkan nilai hasil seperti yang ditampilkan pada Tabel 4 di atas, maka dapat diperoleh dengan contoh perhitungan sebagai berikut ini:

Nilai Hasil $(B C W P)=$ Bobot penyelesain

(\%) x Komulatif Anggaran

$$
\begin{aligned}
& =(100 \%: 100 \%) \times \text { Rp. } 900.000 .000 \\
& =\text { Rp. } 900.000 .000
\end{aligned}
$$

Berdasarkan nilai-nilai yang didapatkan dalam perhitungan variabel nilai hasil, maka sudah mencukupi untuk dilakukan analisa penerapan manajemen waktu pada proyek beton penagkis ombak menggunakan metode nilai hasil. Pada analisa tersebut akan bisa dijelaskan mengenai kinerja jadwal pelaksanaan proyek sekaligus dapat digunakan untuk melakukan pengujian hipotesis penelitian. Variabel-variabel nilai hasil dari proyek yang diteliti pada penelitian ini ditampilkan pada Tabel 5 berikut ini:

Tabel 5. Variabel Nilai Hasil Proyek Beton Penangkis Ombak

\begin{tabular}{|c|c|c|c|c|}
\hline \multirow{2}{*}{$\begin{array}{c}\text { Ming } \\
\text { gu } \\
\text { Ke- }\end{array}$} & $\begin{array}{c}\text { Ha } \\
\text { Ke } \\
\text { ne }\end{array}$ & BCWS & Variabel Nilai Hasil (Rp) & $B C W P$ \\
\hline 1 & 7 & $\begin{array}{c}25.100 .0 \\
00\end{array}$ & $\begin{array}{c}28.000 .0 \\
00\end{array}$ & $\begin{array}{c}49.500 .0 \\
00\end{array}$ \\
\hline 2 & 14 & $\begin{array}{c}78.766 .5 \\
00\end{array}$ & $\begin{array}{c}93.300 .0 \\
00\end{array}$ & $\begin{array}{c}90.000 .0 \\
00\end{array}$ \\
\hline 3 & 21 & $\begin{array}{c}157.443 . \\
100\end{array}$ & $\begin{array}{c}189.077 . \\
500\end{array}$ & $\begin{array}{c}162.000 . \\
000\end{array}$ \\
\hline 4 & 28 & $\begin{array}{c}240.0015 \\
00\end{array}$ & $\begin{array}{c}267.432 . \\
500\end{array}$ & $\begin{array}{c}220.500 . \\
000\end{array}$ \\
\hline 5 & 35 & $\begin{array}{c}345.333 . \\
700\end{array}$ & $\begin{array}{c}352.110 . \\
000\end{array}$ & $\begin{array}{c}306.000 . \\
000\end{array}$ \\
\hline 6 & 42 & $\begin{array}{c}454.556 . \\
100\end{array}$ & $\begin{array}{c}442.611 . \\
000\end{array}$ & $\begin{array}{c}454.500 . \\
000\end{array}$ \\
\hline 7 & 49 & $\begin{array}{c}576.112 . \\
800\end{array}$ & $\begin{array}{c}567.943 . \\
500\end{array}$ & $\begin{array}{c}585.000 . \\
000\end{array}$ \\
\hline 8 & 56 & $\begin{array}{c}702.416 . \\
000\end{array}$ & $\begin{array}{c}718.722 . \\
000\end{array}$ & $\begin{array}{c}630.000 . \\
000\end{array}$ \\
\hline 9 & 63 & $\begin{array}{c}807.358 . \\
000\end{array}$ & $\begin{array}{c}779.510 . \\
500\end{array}$ & $\begin{array}{c}765.000 . \\
000\end{array}$ \\
\hline 10 & 70 & $\begin{array}{c}900.000 . \\
000\end{array}$ & $\begin{array}{c}820.366 . \\
000\end{array}$ & $\begin{array}{c}900.000 . \\
000\end{array}$ \\
\hline
\end{tabular}

Sumber: data diolah

\section{Analisa Kinerja Jadwal Pelaksanaan Proyek Beton Penangkis Ombak}

Seperti yang kita ketahui bersama bahwa dalam konsep nilai hasil menggunakan Kurva $\mathrm{S}$ yang bisa menjelaskan mengenai kondisi kemajuan proyek. Husen (2011) menyatakan bahwa evaluasi proyek untuk mengendalikan waktu adalah bentuk Kurva S yang dimodifikasi menjadi 3 (tiga) variabel, yaitu:

1. Rencana dari volume dan biaya pekerjaan $(B C W S)$.

2. Realisasi dari volume pekerjaan dan rencana biaya $(B C W P)$. 
3. Realisasi biaya dan volume pekerjaan $(A C W P)$.

Lebih lanjut, Husen (2011) menjelaskan bahwa untuk memantau kondisi keuangan proyek dalam pembiayaan proyek, perlu dibuat kurva yang dinamakan Kurva S. Pada pembuatan Kurva S tampilan informasi dengan Sumbu X menunjukkan durasi proyek dan Sumbu Y menyatakan komulatif biayanya. Anggaran komulatif biaya ditunjukkan oleh variabel-variabel nilai hasil meliputi $B C W S$, $B C W P$ dan $A C W P$. Pada Kurva $\mathrm{S}$ yang terbentuk dapat menggambarkan terjadinya perlambatan atau percepatan kinerja proyek dari segi waktu. Berdasarkan atas data variabel nilai hasil yang diperoleh dalam penelitian pada pelaksanaan proyek beton penangkis ombak, maka bentuk Kurva $S$ dapat dilihat pada Gambar 3 sebagai berikut ini.



Gambar 3. Grafik Analisa Varian Terpadu Proyek Beton Penangkis Ombak Disajikan dengan Kurva

Pada Gambar 3 di atas, maka diperlihatkan mengenai variabel $B C W S$, $A C W P$ dan $B C W P$ yang mencerminkan status kinerja jadwal proyek. Pada kurva tersebut tampak bahwa biaya aktual proyek (ACWP) ditandai pada garis berwarna biru, biaya anggaran proyek (BCWS) ditandai dengan garis berwarna hijau dan nilai hasil proyek proyek $(B C W P)$ ditandai dengan garis berwarna merah. Dengan pencapaian posisi ke-3 variabel yang diperlihatkan pada Kurva $S$ yang terbentuk, maka ke-3 variabel tersebut terlihat membentuk kurva dengan variasi yang menunjukkan selisih yang cukup ketat. Terjadi perubahan posisi yang saling bergantian dalam perjalanan waktu pelaksanaan proyek, kadang di atas dan kadang di bawah dari kurva yang terbentuk oleh ke-3 variabel tersebut.

Pada Gambar 3, dapat juga diperlihatkan mengenai kinerja waktu pada obyek penelitian ditampilkan dalam grafik
$\mathrm{S}$

yang disajikan dalam Kurva S. Pada kurva tersebut diperlihatkan bahwa realisasi waktu pengerjaan proyek pada Sumbu $\mathrm{X}$ berjalan melambat bila dibandingkan dengan skedul perencanaan proyek dari minggu ke-1 hingga minggu ke-3 dan progres kemajuan proyek ditunjukkan pada Sumbu Y. Selanjutnya, pada minggu ke-4 hingga minggu ke-8 waktu pelaksanaan proyek berjalan sesuai dengan jadwal rencana proyek dan dapat dikatakan proyek berjalan pada lintasan yang benar (on the right track). Memasuki pada kondisi menjelang batas waktu penyelesaian proyek pada minggu ke-9 dan minggu ke-10, waktu berjalannya proyek menunjukkan adanya percepatan dari jadwal yang direncanakan sehingga proyek beton penangkis ombak bisa selesai dikerjakan dengan tepat waktu (on schedule).

Pada teknik pengendalian proyek dengan menggunakan metode nilai hasil 
(earned value) dari analisa terbentuknya kurva yang dihasilkan atas variabel-variabel $B C W S$, $B C W P$ dan $A C W P$, masih ada analisa lanjutan untuk memperlihatkan secara lebih mendalam untuk lebih meyakinkan kinerja jadwal pada pelaksanaan proyek. Analisa ini dilakukan untuk bisa memperlihatkan status kinerja jadwal proyek per periode pengamatan pada obyek yang diteliti dengan penghitungan indikator varian jadwal (schedule variance). Indikator schedule variance $(S V)$ mempunyai peluang nilai yang akan didapatkan pada pelaksanaan proyek terdiri dari angka negatif, angka positif, atau angka 0. Dengan perolehan nilai yang didapatkan pada penghitungan indikator schedule variance tersebut, akan dapat menjelaskan status proyek berkaitan dengan kinerja jadwal proyek, apakah terjadi percepatan, kelambatan atau tepat jadwal pelaksanaan proyek. Indikator schedule variance dihitung dari pengurangan variabel $B C W S$ terhadap BCWP. Pada penelitian pelaksanaan proyek beton penangkis ombak, didapatkan besaran/indikator schedule variance $(S V)$ terlihat pada Tabel 6 sebagai berikut ini.

Tabel 6. Indikator Schedule Variance (Varian Jadwal) Proyek Beton penangkis Ombak

negarif dan angka 0. Dengan perolehan nilainilai dari indikator $S V$ yang cukup bervariasi tersebut, maka analisa waktu pelaksanaan proyek pada minggu ke-1, ke-2, ke-3 dan minggu ke-7 mengalami keterlambatan dari jadwal waktu yang direncanakan karena $S V$ nya negatif. Selanjutnya pada minggu ke-4, ke-5, ke-6, ke-8 dan ke-9 menunjukkan waktu pelaksanaan proyek mengalami percepatan dari jadwal yang direncanakan karena $S V$-nya positif. Hasil akhirnya pada minggu ke-10, dengan didapatkan nilai $S V=0$ mengindikasikan kinerja jadwal proyek menunjukkan proyek selesai dengan tepat waktu sesuai dengan yang direncanakan . Untuk mendapatkan nilai dari indikator $S V$ seperti yang termuat pada Tabel 6 di atas, maka dicontohkan perhitungan pada minggu ke-10 dengan perhitungan rumus berikut ini:

$$
\begin{aligned}
S V & =B C W S-B C W P \\
& =\text { Rp. } 900.000 .000-\text { Rp. } 900.000 .000 \\
& =0
\end{aligned}
$$

Dengan perolehan nilai-nilai indikator $S V$ yang cukup bervariasi tersebut pada pelaksanaan proyek beton penangkis ombak, maka dapat dijelaskan sebagai berikut:

1. Perolehan indikator $S V$ bernilai negatif dicapai pada pelaksanaan proyek pada \begin{tabular}{|l|l|l}
\hline Minggu ke- & $B C W S(\mathrm{Rp})$ & $B C W P(\mathrm{Rp}$ ) menging ke-1, ke-2, ke-3 dan ke-7;
\end{tabular}

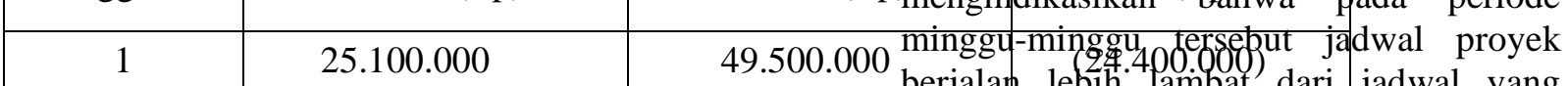

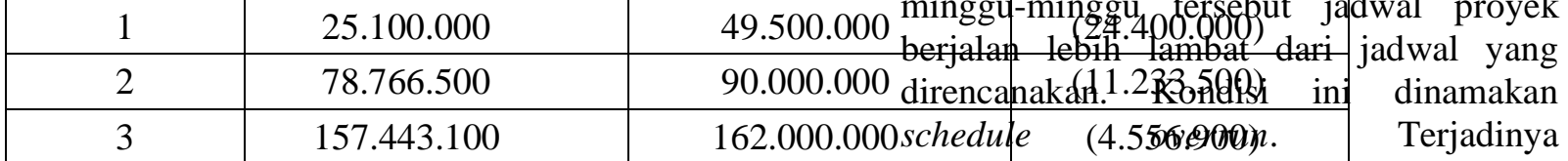

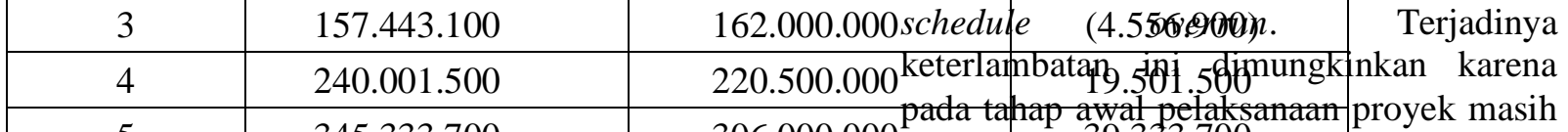

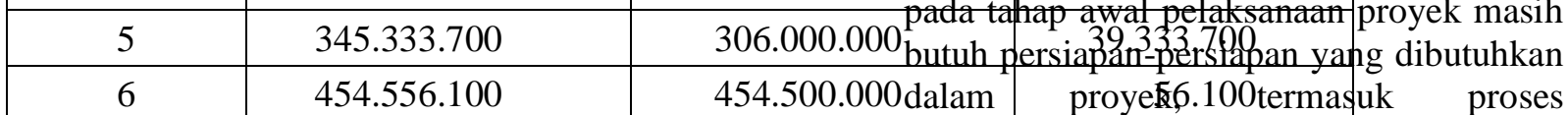
\begin{tabular}{|l|l|l|l}
6 & 454.556 .100 & 454.500 .000 dalam proye 6.100 termasuk proses \\
\hline 7 & 576.112 .800 & 585.000 .000 mendatangka.8.8\%
\end{tabular}

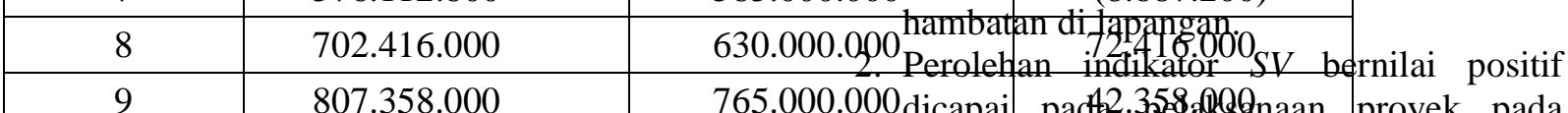
\begin{tabular}{l|l}
10 & 900.000 .000
\end{tabular}

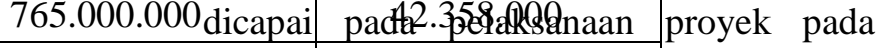
900.000.000minggu ke-4, ke 65 , ke-6, ke-8 dan ke-9;

Sumber: Data diolah

Pada Tabel 6 di atas, berdasarkan pengurangan atas variabel $B C W S$ dengan variabel $B C W P$ yang diperoleh dalam penelitian ini, maka diperlihatkan status proyek yang berkaitan dengan kinerja jadwal proyek dihasilkan dengan $S V$ bernilai positif, mengindikasikan bahwa pada periode minggu-minggu tersebut jadwal proyek berjalan lebih cepat dari jadwal yang direncanakan. Kondisi ini dinamakan schedule underrun. Terjadinya percepatan jadwal pelaksanaan proyek lebih cepat dari yang direncanakan, menunjukkan bahwa pelaksana proyek telah teruji handal dan 
profesional melalui metode perencanaan kerja yang matang sehingga laju proyek bisa berjalan dengan cukup baik.

3. Perolehan indikator $S V$ bernilai angka 0 dicapai pada pelaksanaan proyek minggu ke-10, mengindikasikan bahwa pelaksanaan proyek berlangsung tepat jadwal sesuai dengan jadwal yang direncanakan. Dengan pencapaian atas nilai indikator ini, maka realisasi pelaksanaan proyek beton penangkis ombak selesai dengan jadwal yang telah direncanakan. Kondisi ini dinamakan on schedule. Pencapaian kondisi ini bukan persoalan yang sederhana dan didapatkan dengan begitu saja, melainkan dibutuhkan upaya dan effort yang memadai dalam rangka mencapai sasaran proyek.

Untuk menambah keyakinan dan sekaligus melengkapi dalam analisa dengan menggunakan metode nilai hasil (eaned value) untuk dapat mengetahui status proyek yang berkaitan dengan kinerja waktu, maka analisis dapat dilanjutkan untuk mendapatkan perhitungan nilai indek yang dinamakan schedule performance index (indek kinerja jadwal). Schedule performance index (SPI) dapat diperoleh dengan perhitungan pembagian dari variabel nilai hasil $(B C W P)$ dengan variabel anggaran proyek (BCWS). Berdasarkan atas pelaksanaan proyek beton penangkis ombak didapatkan hasil perhitungan indek dari schedule performance index (SPI) disajikan pada Tabel 7 di bawah ini.

Tabel 7. Indek Kinerja Jadwal (SPI) Proyek Beton Penangkis Ombak

\begin{tabular}{|c|c|c|}
\hline $\begin{array}{c}\text { Minggu } \\
\text { ke- }\end{array}$ & $B C W S(\mathrm{Rp})$ & $B C W P(\mathrm{Rp})$ \\
\hline 1 & 25.100 .000 & 49.500 .000 \\
\hline 2 & 78.766 .500 & 90.000 .000 \\
\hline 3 & 157.443 .100 & 162.000 .000 \\
\hline 4 & 240.001 .500 & 220.500 .000 \\
\hline 5 & 345.333 .700 & 306.000 .000 \\
\hline 6 & 454.556 .100 & 454.500 .000 \\
\hline 7 & 576.112 .800 & 585.000 .000 \\
\hline 8 & 702.416 .000 & 630.000 .000 \\
\hline 9 & 807.358 .000 & 765.000 .000 \\
\hline 10 & 900.000 .000 & 900.000 .000 \\
\hline
\end{tabular}

Sumber: Data diolah
Pada Tabel 7 di atas, berdasarkan atas nilai variabel $B C W S$ dan variabel $B C W P$ yang diperoleh dalam penelitian ini, diperlihatkan performasi status proyek yang berkaitan dengan indek kinerja jadwal proyek atas indek SPI dapat dijelaskan sebagai berikut ini:

1. Performasi berjalannya waktu proyek terjadi kelambatan dari jadwal yang direncanakan pada minggu ke-1, ke-2, ke-3 dan minggu ke-7 karena analisa nilai indek kinerja jadwal (SPI) nilainya di bawah 1.

2. Performasi berjalannya waktu proyek terjadi lebih cepat dari jadwal yang direncanakan pada minggu ke-4,ke-5, ke-8 dan minggu ke-9 karena analisa nilai indek kinerja jadwal (SPI) nilainya di atas 1.

3. Performasi berjalannya proyek menghasilkan ketepatan jadwal pada minggu ke-10 karena analisa nilai indek kinerja jadwal $(S P I)$ nilainya angka 1.

Dengan perolehan nilai indek $S P I=$ 1 pada pelaksanaan proyek beton penangkis ombak, maka mengindikasikan bahwa pelaksanaan proyek berlangsung tepat jadwal (on schedule) sesuai dengan waktu yang direncanakan. Untuk mendapatkan indek SPI sesuai dengan data yang dicantumkan pada tabel tersebut di atas dicontohkan pada minggu ke-10, maka dapat diperoleh dengan perhitungan menggunakan rumus seperti disajikan pada berikut ini:

$$
\begin{aligned}
& S P I=\text { BCWP }: B C W S \\
& =\text { Rp. } 900.000 .000: \text { Rp. } 900.000 .000 \\
& \quad=1
\end{aligned}
$$

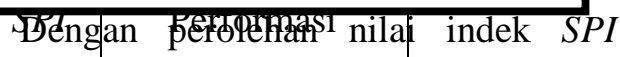
yang didapatkan pada proyek yang menjadi obyek 0,51 penelitiespih Lambat memberikan keyakina 7 bahwabikiharjbatjadwal berjalan dengan0, gad wal LeteplatLarfobai jadwal yang direncangagon dimulai dari tanggal 11 Februari 2019 dan selesai pada tanggal 21 April 2019. Dengan terjadiny debihyefeatian proyek sesuai dengan 1 reffcana Saduail Jgdmgaltelah ditentukan, dapat 0,9Ratakqnebihblambat status proyek berkenaan 1 dengą kinerja jadwal sudah baik ditakukat 6 oleh petaksana proyek. Pelaksana proyek sudah matrebih neenatapkan manajemen waktu proyek Se deargadwademestinya dan membuktikan dalam pengujian hipotesis penelitian ini sebagai berikut: 


$$
\begin{aligned}
& \text { Ho }=\text { Ditolak } \\
& \text { H1 = Diterima }
\end{aligned}
$$

Berdasarkan atas aplikasi dengan menggunakan nilai hasil (earned value) pada proyek beton penangkis ombak yang diteliti ini, analisa divisualisasikan melalui Kurva $S$ dengan menggunakan variabel $B C W S, A C W P$ dan BCWP; analisa dilanjutkan dengan penghitungan indikator $S V$ (schedule variance) dan analisa dilanjutkan lagi dengan penghitungan indek SPI (schedule performance index); kesemua analisa tersebut membuktikan hipotesis penelitian Ho ditolak dan H1 diterima. Dengan demikian interpretasinya dengan hasil pengujian atas hipotesis penelitian tersebut, maka membuktikan bahwa penerapan manajemen waktu proyek (time management) pada proyek beton penangkis ombak menghasilkan ketepatan jawal penyelesaian proyek sesuai dengan yang dijadwalkan (on schedule) pada tanggal 21 April 2020.

\section{PENUTUP}

Pada penelitian tentang analisa penerapan manajemen waktu pada proyek beton penangkis ombak, maka dapat dihasilkan kesimpulan yang mengandung beberapa hal penting sebagai berikut ini:

1. Pengendalian proyek adalah suatu usaha sistematis untuk menentukan standar yang sesuai dengan perencanaan proyek, merancang sistem informasi, membandingkan pelaksanaan dengan standar, menganalisis kemungkinan adanya penyimpangan antara waktu pelaksanaan dengan jadwal yang direncanakan dan mengambil tindakan pembetulan yang diperlukan agar dihasilkan ketepatan jadwal pelaksanaan proyek.

2. Untuk kepentingan analisa penerapan manajemen waktu pada proyek beton penangkis ombak yang diteliti ini, proyek tersebut diamati dalam 10 periode mingguan yang masing-masing periode membutuhkan durasi 7 hari kerja dimulai dari tanggal 11 Februari sampai dengan tanggal 21 April 2020.

3. Berdasarkan analisa penerapan manajemen waktu pada proyek yang diteliti, didapatkan informasi waktu pelaksanaan proyek pada minggu ke-1, ke-2, ke-3 dan minggu ke-7 berjalan dengan lebih lambat dari jadwal yang direncanakan; kemudian pada minggu ke4, ke-5, ke-6, ke-8 dan minggu ke-9 berjalan dengan lebih cepat dari jadwal yang direncanakan; dan akhirnya pada minggu ke-10 pelaksanaan proyek mencapai penyelesaian sesuai dengan jadwal yang direncanakan.

4. Berdasarkan atas analisa kinerja jadwal dengan menggunakan metode nilai hasil (earned value method) pada pelaksanaan proyek beton penangkis ombak, didapatkan hasil perhitungan varian jadwal (schedule variance) $S V=0$ dan indek kinerja jadwal (schedule performance index) SPI $=1$. Dengan demikian, hasil analisa pelaksanaan proyek yang diteliti secara meyakinkan menunjukkan terjadinya jadwal pelaksanaan proyek sesuai dengan jadwal yang telah direncanakan (on schedule).

\section{DAFTAR PUSTAKA}

Ali, T. H. 1995, Prinsip-prinsip Network Planning. Penerbit PT. Gramedia, Jakarta.

Barry, Donald S dan Paulson. 1998. Manajemen Konstruksi Profesional. Erlangga, Jakarta.

Dimyati, H dan Nurjaman, K. 2014. Manajemen Proyek. Penerbit Pustaka Setia, Bandung.

Dipohusodo, I. 1996. Manajemen Proyek dan Konstruksi. Penerbit Kanisius, Jakarta.

Ervianto, Wulfram I. 2004. Teori-Aplikasi Manajemen Proyek Konstruksi. Penerbit Andi Offset, Yogjakarta.

Ervianto, Wulfram I. 2005. Teori-Aplikasi Manajemen Proyek Konstruksi. Penerbit Andi Offset, Yogjakarta.

Flemming Q. W. Dan Koppelman, J. M. 1994. The Essence and Evolution of Earned Value. AACE Transaction, Boston.

Gray, C., Simanjuntak. P., Lien K. S. , Mspaitella, P. F. L. dan Varley, R. C. G. 2007. Pengantar Evaluasi Proyek. Penerbit Gramedia Pustaka Utama, Jakarta.

Handoko, T. H. 1999. Manajemen Personalia dan Sumber Daya Manusia. Penerbit BPFE, Yogjakarta. 
Hughes, Bob dan Mike Cotterell. 2002. Software Project Management. Edisi Ke-3. McGraw-Hill, London.

Husen, Abrar. 2009. Manajemen Proyek. Penerbit Andi Offset, Yogjakarta.

Husen, Abrar. 2011. Manajemen Proyek. Penerbit Andi Offset, Yogjakarta.

Johan, dkk. 1998.Trade-Off Waktu dan Biaya pada Proyek Konstruksi (Studi Kasus pada Proyek Kantor Bank Metro). Jurnal Teknik Sipil Fakultas Teknik Universitas Airlangga, Surabaya.

Kerzner. 1982. Project Management A System Approach Do Planning, Schedulling and Controlling. Van Nostrand Reinhold, New York.

Larson, E. W. 2006. Project Management. First Edition. Bosyo: Irwin McGrawHill, London.

Muljadi. 1998. Analisa Biaya dan Manfaat (Cost and Benefit Analysis). Penerbit, Rineka Cipta, Jakarta.

Nugraha, P. I. Natan dan R. Sutjipto. 1985. Manajemen Proyek Konstruksi Jilid I dan II. Penerbit Kartika Yudha, Surabaya.

Pastiarsa, Made. 2015. Manajemen Proyek Konstruksi Bangunan Industri: Perspektif Pemilik Proyek. Penerbit Teknosain, Yogjakarta.

Project Management Institute USA. 2004. A guide in the Project Management Book of Knowledge (PMBOOK). PMI Inc., Pennsylvania USA.

Rani, Hafnidar A. 2016. Manajemen Proyek Konstruksi. Penerbit Deepublish, Yogjakarta.

Reksohadiprojo, Sukanto. 1983. Manajemen Proyek. Penerbit Liberty, Yogjakarta.

Santoso, Budi. 2003. Manajemen Proyek. Penerbit Graha Ilmu, Yogjakarta.

Santoso, Budi. 2009. Manajemen Proyek: Konsep dan Implementasi. Penerbit Graha Ilmu, Yogjakarta.

Schwalbe, Kathy.2004. Information Technology Project Mangement. Edisi Ke-4 Course Teknology Inc, Boston.

Soeharto, Iman. 1995. Manajemen Proyek: Dari Konseptual sampai Operasional. Penerbit Erlangga, Jakarta.

Soeharto, Iman. 1999. Manajemen Konstruksi dari Konseptual Hingga Operasional. Penerbit Erlangga, Jakarta.
Soeharto, Iman. 2011. Manajemen Konstruksi dari Konseptual Hingga Operasional. Penerbit Erlangga, jakarta.

Sugiyanto. 2020. Manajemen Pengendalian Proyek. Penerbit Scopindo Media Pustaka, Surabaya.

Tjaturono. 2006. Manajemen Konstruksi. Bahan Kuliah Pascasarjana Magister Teknik Institut Teknologi Nasional, Malang.

Triton, P. B. 2005. Manajemen Divestasi Proyek: Analisis \& Strategi. Penerbit Tugu Publisher, Yogjakarta.

Wardjito. 2003. Studi Penelitian Produktivitas Tenaga Kerja Bangunan untuk Meningkatkan Kinerja. Tesis Institut Teknologi Nasional, Malang. 